\title{
Review \\ From Channels to Canonical Wnt Signaling: A Pathological Perspective
}

\author{
Silvia Muccioli $\mathbb{D}^{\mathbb{D}}$, Valentina Brillo, Leonardo Chieregato, Luigi Leanza ${ }^{*}+{ }^{+}$, Vanessa Checchetto ${ }^{\dagger}$ and Roberto Costa ${ }^{\dagger}$ \\ Department of Biology, University of Padova, 35122 Padova, Italy; silvia.muccioli@studenti.unipd.it (S.M.); \\ valentina.brillo@studenti.unipd.it (V.B.); leonardo.chieregato@studenti.unipd.it (L.C.); \\ vanessa.checchetto@unipd.it (V.C.); roberto.costa@unipd.it (R.C.) \\ * Correspondence: luigi.leanza@unipd.it; Tel.: +39-04-9827-6343 \\ † These authors share senior authorship.
}

Citation: Muccioli, S.; Brillo, V.; Chieregato, L.; Leanza, L.; Checchetto, V.; Costa, R. From Channels to Canonical Wnt Signaling: A Pathological Perspective. Int. J. Mol. Sci. 2021, 22, 4613. https://doi.org/ $10.3390 /$ ijms 22094613

Academic Editors: Antonio Ferrer-Montiel and Antonio Felipe

Received: 2 March 2021

Accepted: 26 April 2021

Published: 28 April 2021

Publisher's Note: MDPI stays neutral with regard to jurisdictional claims in published maps and institutional affiliations.

Copyright: (C) 2021 by the authors Licensee MDPI, Basel, Switzerland. This article is an open access article distributed under the terms and conditions of the Creative Commons Attribution (CC BY) license (https:// creativecommons.org/licenses/by/ $4.0 /)$.

\begin{abstract}
Wnt signaling is an important pathway mainly active during embryonic development and controlling cell proliferation. This regulatory pathway is aberrantly activated in several human diseases. Ion channels are known modulators of several important cellular functions ranging from the tuning of the membrane potential to modulation of intracellular pathways, in particular the influence of ion channels in Wnt signaling regulation has been widely investigated. This review will discuss the known links between ion channels and canonical Wnt signaling, focusing on their possible roles in human metabolic diseases, neurological disorders, and cancer.
\end{abstract}

Keywords: Wnt signaling; ion channels; cancer; metabolic diseases; neurological disorders

\section{Introduction}

The Wnt signaling pathway is a group of signaling transduction cascades involved in various physiological processes, including embryonic development, cell stemness maintenance, and tissue regeneration [1]. The term "Wnt" is the combination of two gene annotations, coding homologous proteins in D. melanogaster and M. musculus, respectively wingless (wg) and Mammary tumor virus integration 1(Int1) [2].

Currently, three classes of Wnt signaling pathways have been reported: (i) the canonical Wnt pathway, (ii) the non-canonical planar cell polarity pathway, and (iii) the non-canonical Wnt/calcium pathway [1]. All pathways share a similar initiation of the cascade due to the binding of a Wnt ligand to a Frizzled family receptor. Wnt ligands are small secreted proteins able to diffuse in the extracellular matrix, generating a response paracrine gradient.

The binding of a Wnt ligand triggers canonical Wnt signaling (Figure 1) (e.g., WNT3A) with Frizzled (FZD) and Lipoprotein receptor-related protein 5/6 (LRP5/6), forming a complex [3]. The intracellular domain of this active complex transduces the stimulus inside the cell, inducing the crucial interactor Dishevelled (DVL) recruitment. DVL creates an extensive scaffold for other proteins, including Axin1, Adenomatous polyposis coli (APC), and the glycogen synthase kinase $3 \beta$ (GSK3 $\beta)$, three negative regulators of the $\beta$-catenin, also known as the $\beta$-catenin destruction complex $[4,5]$. Indeed, since $\beta$-catenin is constitutively transcribed, it must be constantly controlled at the post-translational level by this destruction machinery, involving $\beta$-Transducin Repeat Containing E3 Ubiquitin Protein Ligase and the proteasome [6].

On the other end, the inhibition of GSK3 $\beta$ along with the sequestering of Axin1 and APC results in the impairment of the $\beta$-catenin destruction complex and the activation of Wnt pathway [7]. Once activated, $\beta$-catenin is stabilized, and its concentration increases over the threshold level so that it translocates across the nuclear envelope and acts as a co-transcriptional regulator. 


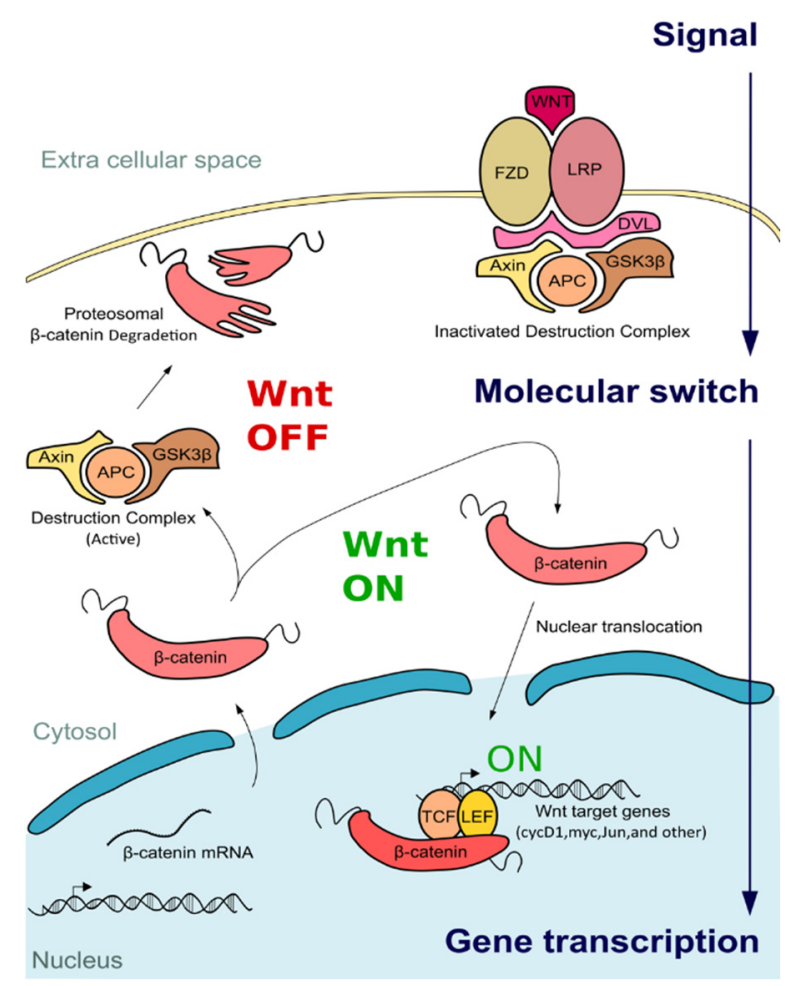

Figure 1. Canonical Wnt signaling cascade. Generally, Wnt signaling is "OFF" since without any stimulus, $\beta$-catenin is degraded by the proteasome after phosphorylation mediated by the destruction complex (including Axin1 (Axin), Adenomatous polyposis coli (APC), and the glycogen synthase kinase $3 \beta$ (GSK3 $\beta)$ ). Conversely, when Wnt ligands bind to the receptors Frizzled (FZD) and Lipoprotein receptor-related protein 5/6 (LRP), Dishevelled (DvI) is recruited and contributes to the destruction complex inactivation. Consequently, $\beta$-catenin is not restricted and can translocate into the nucleus contributing to the activation of the transcription of Wnt-related genes, directly binding the $\mathrm{T}$ cell lymphocyte differentiation factors (TCF) and lymphoid enhancer-binding factor 1 (LEF).

In general, $\beta$-catenin indirectly enables the interaction between lymphoid enhancerbinding factor 1 (LEF1), the T cell lymphocyte differentiation factors (TCFs) and the Wnt responsive element, short DNA sequences located in the promoters of Wnt target genes [1]; however, the transcriptional activation involves the release of Groucho, other repressors, and chromatin remodeling proteins from TCFs [8-10]. This simple event switches the function of TCFs [8], which stops the recruitment of histone deacetylases [8], [11] and primes the association between $\beta$-catenin, RNA polymerase II, and a plethora of transcriptional factors, including CREB binding protein (CBP) and mediator (MED) [12,13]. The intranuclear canonical Wnt signaling phases are a very complex network of interactions (further details about this topic can be found in Anthony et al., 2020 [14]), and may involve unusual partners, which may even revert $\beta$-catenin activity, blocking Wnt mediated transcription. For instance, Hypoxia Inducible Factor $1 \alpha$, and several Sry-related HMG box proteins can bind $\beta$-catenin, hijacking its activity [14-17].

In parallel with the role of the transcriptional activator, the Wnt/ $\beta$-catenin cascade can induce huge changes in cytoskeleton remodeling and endosome dynamics [18-20], altering cell polarity, cell adhesion, proliferation, and migration. Indeed, catenins $(\alpha$-catenin and $\beta$-catenin) were initially identified as structural proteins involved in cytoskeleton formation and cell/cell adhesion due to their engagement in cadherin/F-Actin complexes [21,22]. Altogether, $\beta$-catenin mediated transcriptional activity and release by the cytoskeleton contribute to the whole response of the canonical cascade, affecting the cell physiology and inducing epidermal to mesenchymal transition (EMT) [23].

Among the three different Wnt signaling pathways, the canonical ( $\beta$-catenin-dependent) one is better described in human diseases. Aberrant regulation of this molecular cascade trig- 
gers catastrophic consequences and is related to the insurgence of many human pathologies, including cancer and human birth disorders [24-27]. Canonical Wnt signaling is directly and indirectly modulated by a multitude of different stimuli and events. This form of integration of the signal generates a hub in cellular signaling that finely coordinates cell proliferation, differentiation, and gene expression [1]. In addition, calcium $\left(\mathrm{Ca}^{2+}\right)$ signaling, endoplasmic reticulum (ER) stress, and mitochondrial cation homeostasis have been recently related to Wnt regulation, revealing a new connection between ion fluxes, channels, and Wnt-dependent cellular signaling [28].

Even more, the non-canonical Wnt $\mathrm{Ca}^{2+}$ pathway further complicates this network by its ability in cytoplasmic $\mathrm{Ca}^{2+}$ handling. The ligand WNT5 induces the formation of the ROR2-FZD complex, which in turn activates phospholipase $C$. This event causes the release of the ER-stored $\mathrm{Ca}^{2+}$ by inositol-1,4,5-triphosphate $\left(\mathrm{IP}_{3}\right)$ dependent channel activity and the activation of NFAT signaling cascade by the kinase PKC [29]. In addition, non-canonical Wnt $\mathrm{Ca}^{2+}$ pathway can also tune canonical Wnt signaling [30]. The detrimental action of canonical Wnt signaling in the pathologic context can be related to the role of $\beta$-catenin in the regulation of gene transcription and its role in EMT. Indeed, more than three hundred genes seem to be positively regulated by this transcription factor [31]. For example, the cyclin D1 (CCND1) and the protoncogene myc $(M Y C)$ are up-regulated by $\beta$-catenin, thus inducing G1 to the S phase cell cycle transition. Since this last step is characterized by DNA replication, it ultimately leads to mitosis and cell proliferation [32,33].

\section{Molecular Interplay between Ions, Channels and Wnt Signaling}

The crucial node of cellular signaling is the coordination and the unambiguous transmission of the signal. Cells usually succeed in this task by integrating several stimuli, ensuring the precise signal in the proper cell type, according to the right spatio-temporal frame. Channel proteins, ions, and secondary messengers are crucial mediators in this field, influencing both the cytosolic and the nuclear stages of Wnt signaling. Concerning molecular mechanisms in which ions and channels tune the canonical Wnt, we recapitulate four synergic mechanisms proposed by different research groups $\left(\mathrm{Ca}^{2+}\right.$ mediated $\beta$-catenin nuclear translocation; $\mathrm{Ca}^{2+}$ storage in the ER modulates ER stress mediated Wnt repression; Channels modulate PI3K/AKT cascade and indirectly the canonical Wnt Axis; Aquaporin1 (AQP1) physically participates at the formation of the $\beta$-catenin destruction complex). These events control distinct steps of the canonical cascade, and such stimuli contribute to the whole transduction process in a coordinated fashion, supporting each other in regulating the cellular response.

$\mathrm{Ca}^{2+}$ dynamics finely modulate the $\beta$-catenin nuclear translocation. $\mathrm{Ca}^{2+}$ is a secondary cellular messenger, regulating many proteins and biological events, including Wnt mediators. The activation of ER Ca ${ }^{2+}$ channels (e.g., IP3 receptor Ryanodine receptors, and Orai calcium channels) allows local and transient fluxes of $\mathrm{Ca}^{2+}$, which can perturbate the basal $\mathrm{Ca}^{2+}$ level in the cytosol $(\sim 100 \mathrm{nM})$, generating a sharp and transient increase in $\mathrm{Ca}^{2+}$ concentration $(>2 \mu \mathrm{M})$ [34]. Moreover, $\mathrm{Ca}^{2+}$ is a highly reactive chemical species inside the cell, as it binds acidic residues located on the protein surface, tuning their activities and influencing their interaction with other molecules. On the other hand, $\beta$-catenin is a negatively charged nuclear transcription factor abundant in the cytosol, which cannot passively overcome nuclear membranes, thus ensuring the unambiguous activation of the Wnt pathway. $\mathrm{Ca}^{2+}$ release from the ER contributes to the neutralization of the negatively charged residues of $\beta$-catenin (Figure 2A), enabling its translocation into the nucleus [35], where it can bind its responsive elements located in the Wnt-dependent promoters. 


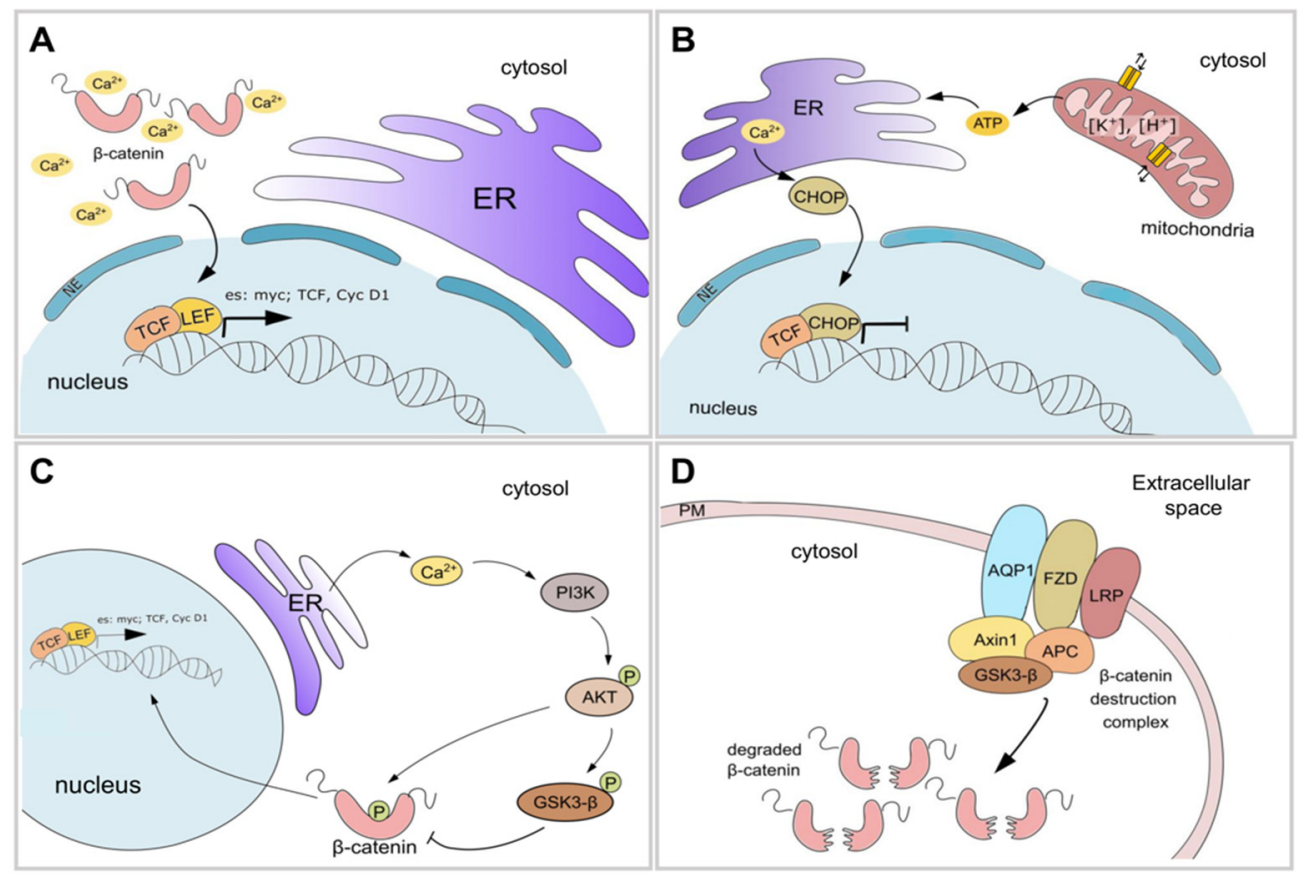

Figure 2. $\mathrm{Ca}^{2+}$ dynamics finely tune canonical Wnt signaling. (A) $\beta$-catenin is a negatively charged protein, which cannot passively overcome nuclear membranes. $\mathrm{Ca}^{2+}$ release from the ER contributes to the neutralization of the negatively charged residues of $\beta$-catenin, enabling its translocation into the nucleus. (B) Mitochondrial homeostasis are requirements for all the cell, including glycolytic ones. Indeed, the mitochondrial ATP synthesis enables $\mathrm{Ca}^{2+}$ storage in the ER. When the ion balance (e.g., $\left[\mathrm{H}^{+}\right],\left[\mathrm{K}^{+}\right]$and/or $\left[\mathrm{Ca}^{2+}\right]$ ) is improper, the ER-stress arise. The ER-stress cascade activates CHOP, which represses Wnt signaling by competing with TCF, ultimately resulting in negative regulation of the Wnt cascade. (C) Wnt signaling is closely interconnected with other pathways, such as the PI3K/AKT pathway, which plays a crucial role in Wnt signaling regulation by modulating GSK3 $\beta$ activity. In this context, $\mathrm{Ca}^{2+}$ concentration plays a critical role in the Wnt/AKT crosstalk. (D) Channel proteins can also contribute to Wnt regulation in a pore-independent manner, such as Aquaporin1 (AQP1). Recent evidence demonstrated that AQP1 physically interacts with GSK3 $\beta$, Axin1, and LRP in a multi-complex platform that eventually promotes complex activity destruction.

A synergic mechanism able to modulate canonical Wnt signaling (independently to the previously described) involves the $\mathrm{Ca}^{2+}$ concentration in the ER, maintained by sarco-endoplasmic reticulum calcium ATPase (SERCA) activity, and the ATP/ADP fluxes between mitochondria and ER are critical determinants in the Wnt response through ER stress level $[17,36]$. Thus, the Krebs cycle modulation or the perturbation of potassium $\left(\mathrm{K}^{+}\right)$ and proton gradient can induce intracellular ER stress development, resulting in increased CHOP (also known as GADD153 or DDIT3) protein levels. CHOP represses Wnt signaling by competing with TCF, the final effector of canonical Wnt signaling cascade, ultimately resulting in negative regulation of the proliferation rate (Figure $2 B$ ) $[37,38]$. Ion balance also contributes to the whole signaling, coordinating different transduction cascades involved in cell proliferation. Several independent authors demonstrated that $\mathrm{K}^{+}$homeostasis can also impact the canonical Wnt signaling. Concerning this point, (i) Koval and colleagues showed that clofazimine, an inhibitor of the $\mathrm{K}^{+}$channel Kv1.3 [39], affects the Wnt signaling and cancer proliferation in triple-negative breast cancer (TNBC) [40]; (ii) Breuer et al. demonstrate that NS1643, a compound able to activate the Kv11.1 channel, attenuates metastasis spread and Wnt signaling in TNBC [41]; (iii) salinomycin, a $\mathrm{K}^{+}$ionophore [42], downregulates the canonical Wnt signaling in chronic lymphocytic leukemia cells and colon cancer cells, similarly to nigericin, ionomycin, and thapsigargin, suggesting that the whole ions balance is involved in this control $[36,43]$.

Wnt signaling is also closely interconnected with other pathways, such as the PI3K/AKT pathway, which plays a crucial role in Wnt signaling regulation by modulating GSK3 $\beta$ activity. Moreover, AKT is a master regulator of a plethora of cellular physiological events, 
such as apoptosis, proliferation, metabolic reprogramming, and cell signaling tuning, which, if dysregulated, results in the emergence of several disorders [44]. In this context, $\mathrm{Ca}^{2+}$ concentration plays a critical role in the Wnt/AKT crosstalk [45]. Thus, the activation of the IP3 receptor induces cytosolic $\mathrm{Ca}^{2+}$ release, which activates PI3K and AKT. Subsequently, AKT both inactivates GSK3 $\beta$ by phosphorylation and promotes $\beta$-catenin activity through direct phosphorylation of Ser-552 in the activation domain. These reactions eventually result in the blocking of the $\beta$-catenin destruction complex, thus favoring its nuclear translocation (Figure 2C) [46].

Channel proteins can also contribute to Wnt regulation in a pore-independent manner, such as AQP1, which seems to act as a scaffold for a multiprotein membrane complex directly involved in the regulation of $\beta$-catenin. Indeed, recent evidence demonstrated that AQP1 physically interacts with GSK3 $\beta$, Axin1, and LRP in a multi-complex platform that eventually promotes the destruction of complex activity (Figure 2D). Hence, loss of AQP1 leads to an increase in $\beta$-catenin stability, however AQPs seems to act in a contextdependent manner; further details will be debated deep in the following paragraphs; additionally, we remind that Aquaporins (AQPs) are poorly selective channels, gating $\mathrm{H}_{2} \mathrm{O}$ but even small ions $[47,48]$.

\section{Channels-Wnt-Dependent Signaling Axes in Diseases}

Ion channels create and dissipate electrochemical gradients, which are required for cell homeostasis by allowing the passage of water, electrolytes, nutrients, or other substrates through the membranes and transporters. Thus, the involvement of ion channels in pathological conditions is not surprising and has been well described in the literature since the late 1980s'. Then, several pieces of evidence have led the scientific community to use the term "channelopathies" to indicate ion channels dysfunctions associated with pathological conditions [49]. In this context, the purpose of the following sections will be to outline the functional links between ion channels and disease development and progression, specifically analyzing channel-Wnt dependent axes involvement in disorder formation. Particularly, we will focus on the newest findings on ion channels modulation of Wnt signaling, unraveling novel insights in cancer and neurological diseases. The following sections will update the state of the art of the widely reported role of channels in canonical Wnt signaling (see several examples in Table 1, further details can be found in [50]) and will provide a comprehensive and focused point of view on those events.

Table 1. Ion Channels involved in Wnt signaling.

\begin{tabular}{ccccc}
\hline Channels & Ions Gated & Effect & Cell Types and Diseases & Ref. \\
\hline Kv7.1, & $\mathrm{K}^{+}$ & $\begin{array}{c}\text { Tumor suppression by inactivation of the B catenin in } \\
\text { the cytoplasm }\end{array}$ & Colon and Hepatic carcinoma \\
\hline Kv11.1 & $\mathrm{K}^{+}$ & $\begin{array}{c}\text { Channel activity inactivates } \beta \text {-catenin, preventing } \\
\text { nuclear importation }\end{array}$ & Breast cancer \\
\hline CFTR & $\mathrm{Cl}^{-}$ & $\begin{array}{c}\text { Tumor suppressor, CFTR activity contributes to the } \\
\text { correct functionality of the complex FZD-LRP-Wnt. }\end{array}$ & Cystic fibrosis \\
\hline TRPV4 & $\mathrm{Ca}^{2+}$ & $\begin{array}{c}\text { TRPV4-mediated Ca }{ }^{2+} \text { entry from the extracellular } \\
\text { space promotes } \beta \text {-catenin activation by AKT } \\
\text { modulation }\end{array}$ & Gastric cancer \\
\hline TrpC5 & $\mathrm{Ca}^{2+}$ & $\begin{array}{c}\text { TrpC5 overexpression favors the nuclear } \\
\text { accumulation of } \beta \text {-catenin by Ca2+ }\end{array}$ & Colorectal cancer \\
\hline
\end{tabular}

\subsection{Channels, Wnt Signaling, and Cancer}

Increasing evidence point out the involvement of ion channels belonging to all the five main ion channels family (potassium, chloride, sodium, calcium and non-selective ion channels) in cancer physiopathology [50]. Some of them have been summed up and functionally divided into onco-suppressors and onco-channels in Tables 2 and 3, specifically focusing on channels involved in regulating Wnt signaling in cancer disease formation and progression. 
Table 2. Onco-suppressors.

\begin{tabular}{|c|c|c|c|c|c|c|}
\hline $\begin{array}{l}\text { Channels } \\
\text { (ion flux) }\end{array}$ & $\begin{array}{l}\text { Expression } \\
\text { in Cancer }\end{array}$ & Cancer Type & $\begin{array}{l}\text { Effects on Wnt } \\
\text { Signaling }\end{array}$ & Mechanism of Action & $\begin{array}{c}\text { Effect on } \\
\text { Tumorigenesis }\end{array}$ & Ref. \\
\hline $\begin{array}{l}\text { CaCNA2D3 } \\
\left(\mathrm{Ca}^{2+}\right)\end{array}$ & Low & $\begin{array}{l}\text { Naso-pharyngeal } \\
\text { carcinoma }\end{array}$ & $\begin{array}{l}\downarrow \text { Wnt signaling } \\
\text { targets (cyclin D1, } \\
\text { c-myc); } \\
\downarrow \text { MMP7 (invasion); } \\
\downarrow \text { SNAIL (EMT) }\end{array}$ & $\begin{array}{l}\uparrow \text { intracellular } \mathrm{Ca}^{2+} \text { flux } \\
\text { causes } \uparrow \text { NLK protein } \\
\text { kinase which antagonize } \\
\text { canonical Wnt signaling }\end{array}$ & $\begin{array}{l}\text { Overexpression induces } \\
\text { mitochondrial- } \\
\text { mediated apoptosis and } \\
\text { repression of } \\
\text { Wnt-dependent } \\
\text { invasion, proliferation } \\
\text { and EMT. }\end{array}$ & [56] \\
\hline $\begin{array}{l}\text { CaCNA2D3 } \\
\left(\mathrm{Ca}^{2+}\right)\end{array}$ & Low & Glioma & $\begin{array}{l}\downarrow \text { Wnt signaling } \\
\text { targets (CCND1, } \\
\text { c-myc); } \\
\downarrow \text { MMP7 (invasion); } \\
\downarrow \text { SNAIL (EMT) }\end{array}$ & $\begin{array}{l}\uparrow \text { intracellular } \mathrm{Ca}^{2+} \text { flux } \\
\text { causes } \uparrow \text { NLK protein } \\
\text { kinase, which antagonize } \\
\text { canonical Wnt signaling }\end{array}$ & $\begin{array}{l}\text { Overexpression induces } \\
\text { mitochondrial- } \\
\text { mediated apoptosis and } \\
\text { repression of } \\
\text { Wnt-dependent } \\
\text { invasion, proliferation } \\
\text { and EMT. }\end{array}$ & [57] \\
\hline $\begin{array}{l}\text { CFTR } \\
\left(\mathrm{Cl}^{-}\right)\end{array}$ & Low & $\begin{array}{l}\text { Colorectal cancer; } \\
\text { Gastric cancer }\end{array}$ & $\begin{array}{l}\downarrow \text { Wnt signaling } \\
\text { targets }\end{array}$ & $\begin{array}{l}\mathrm{CFTR}^{-/-} \mathrm{Apc}^{\mathrm{min}} \text { mice } \\
\text { display } \uparrow W n t / \beta \text {-catenin } \\
\text { target genes (Ccnd1, } \\
\text { CD44, Axin2, Lgr5, } \\
\text { Mmp7, Wnt10A and } \\
\text { Ptgs2) }\end{array}$ & $\begin{array}{l}\mathrm{CFTR}^{-/-} \text {mice } \\
\text { developed significantly } \\
\text { more tumors in the } \\
\text { colon and the entire } \\
\text { small intestine and } \\
\text { alteration in the } \\
\text { intestinal stem cell } \\
\text { compartment. }\end{array}$ & [58] \\
\hline $\begin{array}{c}\mathrm{Kv} 7.1 \\
\left(K^{+}\right)\end{array}$ & Low & Colorectal cancer & $\begin{array}{l}\uparrow \beta \text {-catenin-E- } \\
\text { cadherin } \\
\text { interaction }\end{array}$ & $\begin{array}{l}\text { Membrane depolarization } \\
\text { prevents cytosolic } \\
\beta \text {-catenin release through } \\
\beta \text {-catenin-E-cadherin } \\
\text { complex stabilization }\end{array}$ & $\begin{array}{l}\text { Reduced EMT, cell } \\
\text { proliferation, and } \\
\text { tumorigenesis }\end{array}$ & [51] \\
\hline $\begin{array}{c}\mathrm{Kv11.1} \\
\left(K^{+}\right)\end{array}$ & Low & Breast cancer & $\begin{array}{l}\uparrow \beta \text {-catenin-E- } \\
\text { cadherin } \\
\text { interaction }\end{array}$ & $\begin{array}{l}\text { Membrane depolarization } \\
\text { prevents cytosolic } \\
\beta \text {-catenin release through } \\
\beta \text {-catenin-E-cadherin } \\
\text { complex stabilization } \\
\text { GSK3- } \beta \text {-independent }\end{array}$ & $\begin{array}{l}\text { Represses metastasis } \\
\text { formation }\end{array}$ & [41] \\
\hline
\end{tabular}

Table 3. Onco-channels.

\begin{tabular}{|c|c|c|c|c|c|c|}
\hline $\begin{array}{l}\text { Channels } \\
\text { (ion flux) }\end{array}$ & $\begin{array}{l}\text { Expression } \\
\text { in Cancer }\end{array}$ & Cancer Type & $\begin{array}{l}\text { Effects on Wnt } \\
\text { Signaling }\end{array}$ & Mechanism of Action & Effect on Tumorigenesis & Ref. \\
\hline $\begin{array}{c}\text { Trp5 } \\
\text { (non-selective } \\
\mathrm{Ca}^{2+} \text { cation } \\
\text { channel) }\end{array}$ & High & Colorectal cancer & $\begin{array}{l}\uparrow \text { Wnt5a, } \uparrow \text { Wnt } \\
\text { signaling targets } \\
\text { (cyclin D1 and } \\
\text { c-myc) }\end{array}$ & $\begin{array}{l}\uparrow \text { Trp5 increase } \mathrm{Ca}^{2+} \\
\text { influx in the cell, which } \\
\text { induces } \uparrow W n t 5 \text { and } \uparrow \\
\text { nuclear } \beta \text {-catenin levels }\end{array}$ & $\begin{array}{l}\text { Channel upregulation } \\
\text { reduces colorectal cancer } \\
\text { differentiation and } \\
\text { stemness through } \\
\mathrm{Ca}^{+}-W n t 5 a\end{array}$ & [59] \\
\hline $\begin{array}{c}\text { Trp5 } \\
\text { (non-selective } \\
\mathrm{Ca}^{2+} \text { cation } \\
\text { channel) }\end{array}$ & High & Colorectal cancer & $\begin{array}{l}\beta \text {-catenin } \\
\text { stabilization }\end{array}$ & $\begin{array}{l}\text { Reduction in levels of the } \\
\text { channels reduces } \mathrm{Ca}^{2+} \\
\text { influx lowering } \beta \text {-catenin } \\
\text { stability }\end{array}$ & $\begin{array}{l}\text { Silencing of the channel } \\
\text { reduces colorectal cancer } \\
\text { tumorigenesis and } \\
\text { ameliorates 5-Fluorouracil } \\
\text { chemoresistance }\end{array}$ & [55] \\
\hline $\begin{array}{c}\text { TRPM4 } \\
\text { (non-selective } \\
\mathrm{Ca}^{2+} \text { cation } \\
\text { channel) }\end{array}$ & High & Prostate cancer & $\begin{array}{l}\uparrow \beta \text {-catenin } \\
\text { stabilization }\end{array}$ & $\begin{array}{l}\uparrow \text { GSK } 3 \beta \text { and AKT1 } \\
\text { phospho-inactive form } \\
\text { through } \mathrm{Ca}^{2+} \text { flux }\end{array}$ & $\begin{array}{l}\text { Tumor proliferation and } \\
\text { progression }\end{array}$ & [60] \\
\hline $\begin{array}{c}\text { TRPV2 } \\
\text { (non-selective } \\
\mathrm{Ca}^{2+} \text { cation } \\
\text { channel) }\end{array}$ & High & $\begin{array}{l}\text { Esophageal } \\
\text { squamous cell } \\
\text { carcinoma }\end{array}$ & $\uparrow$ Wnt signaling & $\begin{array}{l}\text { Increased } \mathrm{Ca}^{2+} \text { flux } \\
\text { results in } \uparrow \text { Wnt signaling. } \\
\text { The precise mechanism of } \\
\text { action still to be } \\
\text { determined. }\end{array}$ & $\begin{array}{l}\text { Promotes proliferation, } \\
\text { invasion, and } \\
\text { angiogenesis }\end{array}$ & [61] \\
\hline $\begin{array}{l}\mathbf{B K}_{\mathrm{Ca}} \\
\left(K^{+}\right)\end{array}$ & High & Breast cancer & $\begin{array}{l}\uparrow \beta \text {-catenin } \\
\text { stabilization }\end{array}$ & $\begin{array}{l}\text { Modulation of } \\
\text { transmembrane } \\
\text { depolarization regulates } \\
\text { phospho-AKT and, in } \\
\text { turn, } \beta \text {-catenin stability }\end{array}$ & $\begin{array}{l}\text { Pharmacological } \\
\text { inhibition of the channel } \\
(\text { Ibtx) reduces } \\
\text { anchorage-dependent } \\
\text { growth and tumorigenesis }\end{array}$ & [62] \\
\hline
\end{tabular}


Moreover, ion channels and Wnt signaling interplay in tumors have been thoroughly and nicely reviewed by Mauss et al. [50].

Thus, the purpose of this section will be to shed light on channels and transporters poorly investigated up to now, especially focusing on AQPs and subcellular channels (i.e., mitochondrial and endoplasmic reticulum ion channels) modulation of Wnt signaling in the context of cancer.

AQPs belong to the major intrinsic protein (MIP) family and consist of ubiquitous tissue and organ-specific channels regulating water flux and small molecules trafficking across cell membranes [48]. Furthermore, several members of the MIP family have been shown to function as ion channels, including AQP0, AQP1, AQP6, while other mammalian AQPs may also serve as ion channels when activated by an appropriate stimulus [63]. Due to the crucial part played by fluid balancing in the regulation of physiological processes, $\mathrm{AQPs}$ are reported to be involved in a large variety of cellular mechanisms, including functional changes in cancer cells, mostly linked to stemness maintenance associated with the regulation of canonical Wnt signaling [64]. Although the exact mechanism is still poorly understood, emerging evidence shows that AQPs influence the expression of Wnt downstream signaling molecules, ultimately distinguishing these channels as a possible Wnt-related cancer prognostic marker [64].

Emerging data reveal the existence of an interplay between AQP3 and canonical Wnt signaling in tumors, although contrasting results have been obtained, probably due to tissue-specific expression and function of this channel. Indeed, in 2016, Zhou et al. demonstrated that AQP3 promotes stem-like hallmarks in human gastric cancer cells, enhancing CD44 levels through Wnt/GSK3 $\beta / \beta$-catenin signaling pathway. AQP3 overexpression in human gastric cancer cells is associated with an increase in the level of phosphorylated GSK3 $\beta$ inactive form, resulting in a rise of nuclear $\beta$-catenin [65]. On the contrary, low levels of AQP3 affect stemness maintenance in human lung cancer stem cells, upregulating the Wnt/GSK3 $\beta$ / $\beta$-catenin pathway and Hippo pathway and resulting in altered differentiation and apoptotic processes. Thus, AQP3 influences the expression of canonical Wnt signaling cascade, eventually affecting the proliferation and metastasis formation in lung cancer cells [64].

Furthermore, overexpression of AQP9 is reported to suppress the levels of GSK3 $\beta$, cyclin D1, and $\beta$-catenin in hepatocellular carcinoma cells, enhancing cell apoptosis and inhibiting tumor growth and metastasis formation both in in vitro and in in vivo studies [66], while AQP5 enriches for cancer-driving stem cells in Lgr5+ intestinal cells, the significant sources of cancer following Wnt pathway hyper-activation in mice distal stomach [67].

Concerning intracellular channels, emerging hints suggest that mitochondrial ion channels, which strongly impact mitochondrial function regulation, could be addressed as potential oncological targets against cancer diseases $[68,69]$. For this reason, research in this field is rapidly expanding, so that the role of some mitochondrial ion channels able to modulate Wnt-signaling in cancerous cells has already been clarified.

Indeed in 2019, Costa et al. demonstrated that treatment with sublethal doses of mitochondrial voltage-gated $\mathrm{K}^{+}$channel Kv1.3 inhibitors (PAPTP and PCARBTP) [69] could downregulate Wnt/ $\beta$-catenin signaling in vitro in colon cancer cells and in vivo in zebrafish models by reducing mitochondrial ATP production, which, in turn, impairs $\mathrm{Ca}^{2+}$ uptake in the ER, thus enhancing ER-stress levels [36].

Along with these findings, KCNA1, encoding the voltage-gated $\mathrm{K}^{+}$channel Kv1.1, resulted in being an oncogene strongly expressed in cervical cancer, supporting carcinogenesis by upregulation of Hedgehog, Wnt, and Notch signaling pathways and, eventually, affecting mitochondrial function [70].

Wnt, Hippo, and Notch signaling are all affected by mutations that impair the SarcoEndoplasmic Reticulum Calcium ATPase (SERCA) pump functional activity in the ER, as demonstrated in the in vivo Drosophila model by Suisse et al. [71]. Concerning Wnt signaling impairment, SERCA activity is crucial for $\beta$-catenin/E-cadherin detachment, while Notch and Hippo pathways remain disrupted only at intermediate levels. In this 
sense, using SERCA inhibitors as cancer therapeutics could be complicated by the differential response of the three oncogenic signaling cascades in cancer disease, suggesting new exciting insights to be taken into account during chemotherapeutic tumor treatment [71].

\subsection{Ion Channels and Wnt Signaling Regulation in Neurodegeneration and Neurological Diseases}

Wnt signaling contribution in the insurgence and the progression of neurodegenerative diseases has only recently been discovered. Because of Wnt fundamental role in orchestrating different neuronal functions in the central nervous system (as, for example, neurogenesis, synapse formation, differentiation, neuroprotection, synaptic plasticity, the integrity of the blood-brain barrier, and biology of microglia), the dysregulation of these pathways has emerged as a crucial player in the pathogenesis of common neurological disorders, such as Parkinson's disease (PD), Alzheimer's disease (AD) and other neurodegenerative diseases, like amyotrophic lateral sclerosis (ALS) [72].

In $\mathrm{AD}$, Wnt signaling impairment accelerates the onset of the disease and provokes the development of three AD hallmarks: (i) the production and aggregation of $\beta$-amyloid; (ii) tau protein hyper-phosphorylation process that involves GSK3 $\beta$ and Dikkopf 1 (DKK1), and generates neurofibrillary tangles within neurons; (iii) hippocampal-dependent cognitive impairment [73-75].

In PD, the evidence of relationships among the early stage of the disease and dysregulated Wnt signaling has been elucidated in the latest years, mainly due to the prominent role of this pathway in the control of midbrain dopaminergic neurons survival and development but also the neuronal rescue and regeneration of PD midbrain [76,77].

The role of Wnt signaling is highly debated in ALS, where the degeneration of motor neurons in the brain cortex could be partly due to the alterations of some Wnt effectors, in particular the dysregulation in $\beta$-catenin homeostasis $[78,79]$.

New evidence revealed a direct regulation of the Wnt/ $\beta$-catenin signaling pathway over channels in neurodegeneration. Specifically, the $\alpha 7$-nicotinic acetylcholine receptor (CHRNA7), a Ca ${ }^{2+}$ channel, could represent a potential therapeutic target for neurodegenerative diseases. In $\mathrm{AD}$, its level is drastically reduced in neocortical and hippocampal neurons, together with reducing acetylcholine. It has been demonstrated that activation of canonical Wnt signaling by WNT7A induces CHRNA7 expression and assembly because its gene promoter contains T-cell factor/lymphoid enhancer factor (TCF/LEF) sites [80,81].

Moreover, in PD, Wnt signaling is a critical effector of CHRNA7-induced protection of dopaminergic neurons, suppressing neuroinflammation [82]. McQuate et al., demonstrated a non-canonical Wnt cascade involving WNT5, tyrosine kinase-like orphan receptor 2 (ROR2), G protein and PLC, that decreases $\mathrm{K}^{+}$current and mobilizes intracellular $\mathrm{Ca}^{2+}$ from voltage-gated $\mathrm{Ca}^{2+}$ channels to upregulate the trafficking of $\mathrm{N}$-methyl-D-aspartate receptors (NMDARs) into synapses, in a SNARE dependent fashion. This mechanism could be of great importance in neuropsychiatric disorders, such as $\mathrm{AD}$, where deregulation of NMDARs occurs [83].

On the other side, only few recent discoveries remark the influence of channels on Wnt signaling. As for cancer and metabolic diseases, even in AD, AQPS has been demonstrated to play an important role in the pathogenesis of the disease. Indeed, the higher expression of AQP1 inhibits Wnt signaling in a mouse AD model, whereas its silencing could activate the pathway, alleviating neuronal apoptosis and improving cognitive function [84].

New insights in the AD non-amyloidogenic pathway that block $A \beta$ production and generate soluble amyloid precursor protein $\alpha(\mathrm{APP}-\alpha)$, granting neuroprotection, showed an interplay among NMDARs and Wnt signaling. In particular, NMDAR activation stimulates the secretion of WNT3A, which in turn activates extracellular signal-regulated kinases (ERKs), to elicit A disintegrin and metalloproteinase 10 (ADAM10) —one of the leading $\alpha$-secretase candidates - responsible for the non-amyloidogenic pathway-expression, likely via $\beta$-catenin regulation [75]. 


\subsection{Channels, Wnt Signaling in Other Diseases}

Several studies show the importance of the interplay between ion channels and Wnt signaling in the insurgence of metabolic disorders. In this respect, $\mathrm{Ca}^{2+}$ homeostasis has been demonstrated to be essential for the maintenance of bone marrow mesenchymal stem cells. Considering the $\mathrm{Ca}^{2+}$ TRP channel superfamily, it has been elucidated that an impairment in the activity of these channels is related to a decreased $\mathrm{Ca}^{2+}$ flux that ultimately downregulates Wnt $/ \beta$-catenin signaling, leading to the dysregulation of osteogenic differentiation [85]. Another important channel involved in this process is the Cav1.2. Downregulation of $\mathrm{Ca}_{V} 1.2$ has been found in aging models characterized by an altered osteogenic differentiation that is ultimately caused by the inhibition of the canonical Wnt signaling pathway [86]. Thus, targeting $\mathrm{Ca}^{2+}$ channels and homeostasis can be a promising strategy for bone diseases like osteoporosis.

Regarding the role of other cation channels, we can consider polycystins in developing autosomal-dominant polycystic kidney disease (ADPKD) [87]. Polycystins are a class of nonselective cation channels encoded by PKD1 and PKD2 genes, involved in the transport of $\mathrm{Ca}^{2+}$ inside the cell. Mutations in such genes represent the leading cause of ADPKD development [88]. In particular, Lee et al. suggested the existence of a PKD1/TAZ/Wnt/ $\beta$ catenin/MYC signaling axis in which is proposed the essential interaction between PKD1 and TAZ. In fact, in the absence of PKD1, TAZ can strongly interact with Axin1, weakening its interaction with $\beta$-catenin and inducing the overexpression of c-MYC that lastly leads to the insurgence of renal cystogenesis. Targeting this axis, thus, can be beneficial to decrease ADPKD progression [87].

The importance of AQP1 in ADPKD development has recently been proved, specifically demonstrating that AQP1 deficiency promotes cysts growth through the stimulation of the Wnt signaling cascade [47].

In addition, aquaporins also seem to have an important role in endometriosis. Shu et al. observed that silencing of AQP1, which is upregulated in endometriosis disease, induces the activation of the Wnt signaling pathway that results in a decreased adhesion, invasion, and in the induction of apoptosis of ectopic cells [89].

Finally, regarding anion channels, Lu et al. have demonstrated the importance of the chloride channel $\mathrm{ClC}-2$ in proper blood vessel development in human brain vascular smooth muscle cells (HBVSMCs). The block of this channel activity mediates a decreased $\mathrm{Cl}^{-}$efflux linked to the inhibition of the Wnt/ $\beta$-catenin pathway. Therefore, this channel can be a promising target for preventing hyperplasia, strokes, and cerebrovascular remodeling [90].

\section{Conclusions and Future Perspective}

This review summarized the major known mechanisms involved in Wnt signaling regulation by channels, ion fluxes, and transporters. Some interesting points emerged from our analysis. Firstly, many pieces of evidence lead to the idea that variation in $\mathrm{K}^{+}$and $\mathrm{Ca}^{2+}$ fluxes across cell membrane induced by changes in transmembrane potential can modulate canonical Wnt-signaling [41,51,62]. In addition, this first point is directly linked to our second conclusion: proofs indicate that distinct channels (i.e., Kv 7.1, CFTR, etc.) may have a part in the formation of multiprotein membrane complexes that modulate the correct cytoplasmic-nuclear localization of $\beta$-catenin by physical interaction [41,51]. Thus, shedding light on the functional action of membrane polarization and plasma membrane channels upon $\beta$-catenin stability would be of great interest for future studies. Furthermore, in the latest years, new evidences on modulation of Wnt signaling by tuning organellar channels are arising, so new hints, as well as new possible modulators, will be proposed in the near future.

The second aim of this review was to elucidate the consequences of the channels-Wnt signaling cascade in different diseases. As clearly reported in the literature, the Wnt/ $\beta$ catenin pathway is the most associated with channels regulation in cancer disease development and progression [50]. Indeed, the subdivision in onco-channels and onco-suppressors 
Wnt-regulating proteins certainly corroborates the hypothesis of an ion channels-Wnt signaling axis in cancer. Still, how channels interact with $\beta$-catenin or other proteins involved in Wnt cascade sometimes remains elusive and further investigation should be pursued, as for TRPM7, Nav1.5 and CLC-3 onco-channels (in neuroblastoma, oral squamous cell carcinoma and colorectal cancer, respectively) and ClCa1 oncosuppressor (colorectal cancer) [91-94]. Nevertheless, many data support the idea that inhibition [36,62] or pharmacological activation [41] could be used to properly induce differentiation and tumor aggressiveness arrest via Wnt modulation. Thus, we expect to see an increase in the employ of such treatments in future (pre) clinical studies, possibly using channels levels of expression as prognostic biomarkers due to their contribution to the process of tumorigenesis.

Although the interplay between ion channels and oncogenesis has been unequivocally described, more in-depth investigations about their role in modulating cancerous-unrelated signaling pathways still need to be carried out in other pathologies.

According to the novel findings summarized above, ion channels could be accounted as new Wnt-dependent markers for different pathological conditions, representing invaluable predictive factors for early-onset disease detection and possibly identifying new druggable targets.

Author Contributions: Writing_original draft preparation, V.B., L.C., S.M., R.C., V.C. and L.L.; writing-review and editing, V.C., R.C. and L.L.; supervision, L.L.; funding acquisition, L.L. All authors have read and agreed to the published version of the manuscript.

Funding: The research leading to these results has received funding from Italian Association for Cancer Research (AIRC) under MFAG 2019-ID. 23271 project-P.I. Leanza Luigi. L.L. is also grateful for PRID 2017 grant (n. BIRD162511) from the University of Padova.

Conflicts of Interest: The authors declare no conflict of interest.

\section{References}

1. Sharma, M.; Pruitt, K. Wnt Pathway: An Integral Hub for Developmental and Oncogenic Signaling Networks. Int. J. Mol. Sci. 2020, 21, 8018. [CrossRef]

2. Wodarz, A.; Nusse, R. Mechanisms of Wnt signaling in development. Annu. Rev. Cell Dev. Biol. 1998, 14, 59-88. [CrossRef]

3. MacDonald, B.T.; He, X. Frizzled and LRp5/6 receptors for wnt/ $\beta$-catenin signaling. Cold Spring Harb. Perspect. Biol. 2012, 4. [CrossRef]

4. Fiedler, M.; Mendoza-Topaz, C.; Rutherford, T.J.; Mieszczanek, J.; Bienz, M. Dishevelled interacts with the DIX domain polymerization interface of Axin to interfere with its function in down-regulating $\beta$-catenin. Proc. Natl. Acad. Sci. USA 2011, 108, 1937-1942. [CrossRef]

5. Taelman, V.F.; Dobrowolski, R.; Plouhinec, J.-L.; Fuentealba, L.C.; Vorwald, P.P.; Gumper, I.; Sabatini, D.D.; De Robertis, E.M. Wnt Signaling Requires Sequestration of Glycogen Synthase Kinase 3 inside Multivesicular Endosomes. Cell 2010, 143, 1136-1148. [CrossRef] [PubMed]

6. Liu, C.; Kato, Y.; Zhang, Z.; Do, V.M.; Yankner, B.A.; He, X. -Trcp couples -catenin phosphorylation-degradation and regulates Xenopus axis formation. Proc. Natl. Acad. Sci. USA 1999, 96, 6273-6278. [CrossRef]

7. Ikeda, S.; Kishida, S.; Yamamoto, H.; Murai, H.; Koyama, S.; Kikuchi, A. Axin, a negative regulator of the Wnt signaling pathway, forms a complex with GSK-3 $\beta$ and $\beta$-catenin and promotes GSK-3 $\beta$-dependent phosphorylation of $\beta$-catenin. EMBO J. 1998, 17. [CrossRef]

8. Daniels, D.L.; I Weis, W. $\beta$-catenin directly displaces Groucho/TLE repressors from Tcf/Lef in Wnt-mediated transcription activation. Nat. Struct. Mol. Biol. 2005, 12, 364-371. [CrossRef]

9. Cavallo, R.A.; Cox, R.T.; Moline, M.M.; Roose, J.; Polevoy, G.A.; Clevers, H.; Peifer, M.; Bejsovec, A. Drosophila Tcf and Groucho interact to repress Wingless signalling activity. Nat. Cell Biol. 1998, 395, 604-608. [CrossRef]

10. Song, H.; Goetze, S.; Bischof, J.; Spichiger-Haeusermann, C.; Küster, M.; Brunner, E.; Basler, K. Coop functions as a corepressor of Pangolin and antagonizes Wingless signaling. Genes Dev. 2010, 24, 881-886. [CrossRef]

11. Billin, A.N.; Thirlwell, H.; Ayer, D.E. $\beta$-Catenin-Histone Deacetylase Interactions Regulate the Transition of LEF1 from a Transcriptional Repressor to an Activator. Mol. Cell. Biol. 2000, 20, 6882-6890. [CrossRef] [PubMed]

12. Kim, S.; Xu, X.; Hecht, A.; Boyer, T.G. Mediator Is a Transducer of Wnt/ $\beta$-Catenin Signaling. J. Biol. Chem. 2006, 281, 14066-14075. [CrossRef]

13. Che, M.; Kweon, S.-M.; Teo, J.-L.; Yuan, Y.-C.; Melstrom, L.G.; Waldron, R.T.; Lugea, A.; Urrutia, R.A.; Pandol, S.J.; Lai, K.K.Y. Targeting the CBP/ $\beta$-Catenin Interaction to Suppress Activation of Cancer-Promoting Pancreatic Stellate Cells. Cancers 2020, 12, 1476. [CrossRef] 
14. Anthony, C.C.; Robbins, D.J.; Ahmed, Y.; Lee, E. Nuclear Regulation of Wnt/ $\beta$-Catenin Signaling: It's a Complex Situation. Genes 2020, 11, 886. [CrossRef]

15. Majmundar, A.J.; Lee, D.S.M.; Skuli, N.; Mesquita, R.C.; Kim, M.N.; Yodh, A.G.; Nguyen-McCarty, M.; Li, B.; Simon, M.C. HIF modulation of Wnt signaling regulates skeletal myogenesis in vivo. Development 2015, 142. [CrossRef]

16. Kaidi, A.; Williams, A.C.; Paraskeva, C. Interaction between $\beta$-catenin and HIF-1 promotes cellular adaptation to hypoxia. Nat. Cell Biol. 2007, 9, 210-217. [CrossRef]

17. Sinner, D.; Kordich, J.J.; Spence, J.R.; Opoka, R.; A Rankin, S.; Lin, S.-C.J.; Jonatan, D.; Zorn, A.M.; Wells, J.M. Sox17 and Sox4 Differentially Regulate $\beta$-Catenin/T-Cell Factor Activity and Proliferation of Colon Carcinoma Cells. Mol. Cell. Biol. 2007, 27, 7802-7815. [CrossRef]

18. Sorrenson, B.; Cognard, E.; Lee, K.L.; Dissanayake, W.C.; Fu, Y.; Han, W.; Hughes, W.E.; Shepherd, P.R. A Critical Role for $\beta$ Catenin in Modulating Levels of Insulin Secretion from $\beta$-Cells by Regulating Actin Cytoskeleton and Insulin Vesicle Localization. J. Biol. Chem. 2016, 291, 25888-25900. [CrossRef]

19. Colozza, G.; Koo, B. Wnt/ $\beta$-catenin signaling: Structure, assembly and endocytosis of the signalosome. Dev. Growth Differ. 2021, 63, 199-218. [CrossRef]

20. Lorzadeh, S.; Kohan, L.; Ghavami, S.; Azarpira, N. Autophagy and the Wnt signaling pathway: A focus on Wnt/ $\beta$-catenin signaling. Biochim. Biophys. Acta BBA Bioenerg. 2021, 1868, 118926. [CrossRef]

21. Schneider, S.; Herrenknecht, K.; Butz, S.; Kemler, R.; Hausen, P. Catenins in Xenopus embryogenesis and their relation to the cadherin-mediated cell-cell adhesion system. Development 1993, 118, 629-640. [CrossRef]

22. Kemler, R. From cadherins to catenins: Cytoplasmic protein interactions and regulation of cell adhesion. Trends Genet. 1993, 9 , 317-321. [CrossRef]

23. Huels, D.J.; Ridgway, R.A.; Radulescu, S.; Leushacke, M.; Campbell, A.D.; Biswas, S.; Leedham, S.; Serra, S.; Chetty, R.; Moreaux, G.; et al. E-cadherin can limit the transforming properties of activating $\beta$-catenin mutations. EMBO J. 2015, 34 . [CrossRef]

24. Martin-Orozco, E.; Sanchez-Fernandez, A.; Ortiz-Parra, I.; Nicolas, M.A.-S. WNT Signaling in Tumors: The Way to Evade Drugs and Immunity. Front. Immunol. 2019, 10, 2854. [CrossRef]

25. Zancan, I.; Bellesso, S.; Costa, R.; Salvalaio, M.; Stroppiano, M.; Hammond, C.; Argenton, F.; Filocamo, M.; Moro, E. Glucocerebrosidase deficiency in zebrafish affects primary bone ossification through increased oxidative stress and reduced Wnt/ $\beta$-catenin signaling. Hum. Mol. Genet. 2014, 24, 1280-1294. [CrossRef]

26. Wang, Y.; Li, Y.P.; Paulson, C.; Shao, J.Z.; Zhang, X.; Wu, M.; Chen, W. Wnt and the Wnt signaling pathway in bone development and disease. Front. Biosci. Landmark 2014, 19, 379. [CrossRef]

27. Berwick, D.C.; Harvey, K. The importance of Wnt signalling for neurodegeneration in Parkinson's disease. Biochem. Soc. Trans. 2012, 40, 1123-1128. [CrossRef] [PubMed]

28. Peruzzo, R.; Costa, R.; Bachmann, M.; Leanza, L.; Szabò, I. Mitochondrial Metabolism, Contact Sites and Cellular Calcium Signaling: Implications for Tumorigenesis. Cancers 2020, 12, 2574. [CrossRef] [PubMed]

29. Clark, C.E.; Nourse, C.C.; Cooper, H.M. The Tangled Web of Non-Canonical Wnt Signalling in Neural Migration. Neurosignals 2012, 20, 202-220. [CrossRef]

30. Yang, K.; Wang, X.; Zhang, H.; Wang, Z.; Nan, G.; Li, Y.; Zhang, F.; Mohammed, M.K.; Haydon, R.C.; Luu, H.H.; et al. The evolving roles of canonical WNT signaling in stem cells and tumorigenesis: Implications in targeted cancer therapies. Lab. Investig. 2016, 96, 116-136. [CrossRef]

31. Herbst, A.; Jurinovic, V.; Krebs, S.; E Thieme, S.; Blum, H.; Göke, B.; Kolligs, F.T. Comprehensive analysis of $\beta$-catenin target genes in colorectal carcinoma cell lines with deregulated Wnt/ $\beta$-catenin signaling. BMC Genom. 2014, 15, 74. [CrossRef]

32. Montalto, F.I.; De Amicis, F. Cyclin D1 in Cancer: A Molecular Connection for Cell Cycle Control, Adhesion and Invasion in Tumor and Stroma. Cells 2020, 9, 2648. [CrossRef]

33. Wong, M.; Joyson, S.; Hermeking, H.; Chiu, S. Transcription Factor AP4 Mediates Cell Fate Decisions: To Divide, Age, or Die. Cancers 2021, 13, 676. [CrossRef]

34. Clapham, D.E. Calcium Signaling. Cell 2011, 131, 1047-1058. [CrossRef]

35. Thrasivoulou, C.; Millar, M.; Ahmed, A. Activation of Intracellular Calcium by Multiple Wnt Ligands and Translocation of $\beta$-Catenin into the Nucleus. J. Biol. Chem. 2013, 288, 35651-35659. [CrossRef] [PubMed]

36. Costa, R.; Peruzzo, R.; Bachmann, M.; Montà, G.D.; Vicario, M.; Santinon, G.; Mattarei, A.; Moro, E.; Quintana-Cabrera, R.; Scorrano, L.; et al. Impaired Mitochondrial ATP Production Downregulates Wnt Signaling via ER Stress Induction. Cell Rep. 2019, 28, 1949-1960.e6. [CrossRef]

37. Horndasch, M.; Lienkamp, S.; Springer, E.; Schmitt, A.; Pavenstädt, H.; Walz, G.; Gloy, J. The C/EBP homologous protein CHOP (GADD153) is an inhibitor of Wnt/TCF signals. Oncogene 2006, 25. [CrossRef]

38. Zhang, Q.-L.; Lian, D.-D.; Zhu, M.J.; Li, X.M.; Lee, J.K.; Yoon, T.-J.; Lee, J.-H.; Jiang, R.-H.; Kim, C.D. Antitumor Effect of Albendazole on Cutaneous Squamous Cell Carcinoma (SCC) Cells. BioMed Res. Int. 2019, 2019, 1-9. [CrossRef] [PubMed]

39. Zaccagnino, A.; Managò, A.; Leanza, L.; Gontarewitz, A.; Linder, B.; Azzolini, M.; Biasutto, L.; Zoratti, M.; Peruzzo, R.; Legler, K.; et al. Tumor-reducing effect of the clinically used drug clofazimine in a SCID mouse model of pancreatic ductal adenocarcinoma. Oncotarget 2016, 8, 38276-38293. [CrossRef] [PubMed] 
40. Koval, A.; Vlasov, P.; Shichkova, P.; Khunderyakova, S.; Markov, Y.; Panchenko, J.; Volodina, A.; Kondrashov, F.; Katanaev, V. Anti-leprosy drug clofazimine inhibits growth of triple-negative breast cancer cells via inhibition of canonical Wnt signaling. Biochem. Pharmacol. 2014, 87, 571-578. [CrossRef] [PubMed]

41. Breuer, E.-K.; Fukushiro-Lopes, D.; Dalheim, A.; Burnette, M.; Zartman, J.; Kaja, S.; Wells, C.; Campo, L.; Curtis, K.J.; RomeroMoreno, R.; et al. Potassium channel activity controls breast cancer metastasis by affecting $\beta$-catenin signaling. Cell Death Dis. 2019, 10, 1-15. [CrossRef]

42. Manago, A.; Leanza, L.; Carraretto, L.; Sassi, N.; Grancara, S.; Quintanacabrera, R.; Trimarco, V.; Toninello, A.; Scorrano, L.; Trentin, L.; et al. Early effects of the antineoplastic agent salinomycin on mitochondrial function. Cell Death Dis. 2015, 6, e1930. [CrossRef]

43. Lu, D.; Choi, M.Y.; Yu, J.; Castro, J.E.; Kipps, T.J.; Carson, D.A. Salinomycin inhibits Wnt signaling and selectively induces apoptosis in chronic lymphocytic leukemia cells. Proc. Natl. Acad. Sci. USA 2011, 108, 13253-13257. [CrossRef]

44. Hers, I.; Vincent, E.E.; Tavaré, J.M. Akt signalling in health and disease. Cell. Signal. 2011, 23, 1515-1527. [CrossRef]

45. Divolis, G.; Mavroeidi, P.; Mavrofrydi, O.; Papazafiri, P. Differential effects of calcium on PI3K-Akt and HIF-1 $\alpha$ survival pathways. Cell Biol. Toxicol. 2016, 32, 437-449. [CrossRef]

46. Fang, D.; Hawke, D.; Zheng, Y.; Xia, Y.; Meisenhelder, J.; Nika, H.; Mills, G.B.; Kobayashi, R.; Hunter, T.; Lu, Z. Phosphorylation of $\beta$-Catenin by AKT Promotes $\beta$-Catenin Transcriptional Activity. J. Biol. Chem. 2007, 282, 11221-11229. [CrossRef]

47. Wang, W.; Weiling, W.; Sun, Y.; Lei, L.; Zhou, H.; Lei, T.; Xia, Y.; Verkman, A.S.; Yang, B. Aquaporin-1 retards renal cyst development in polycystic kidney disease by inhibition of Wnt signaling. FASEB J. 2015, 29, 1551-1563. [CrossRef] [PubMed]

48. Meli, R.; Pirozzi, C.; Pelagalli, A. New Perspectives on the Potential Role of Aquaporins (AQPs) in the Physiology of Inflammation. Front. Physiol. 2018, 9, 101. [CrossRef]

49. Prevarskaya, N.; Skryma, R.; Shuba, Y. Ion Channels in Cancer: Are Cancer Hallmarks Oncochannelopathies? Physiol. Rev. 2018, 98, 559-621. [CrossRef]

50. Rapetti-Mauss, R.; Berenguier, C.; Allegrini, B.; Soriani, O. Interplay Between Ion Channels and the Wnt/ $\beta$-Catenin Signaling Pathway in Cancers. Front. Pharmacol. 2020, 11, 525020. [CrossRef]

51. Rapetti-Mauss, R.; Bustos, V.; Thomas, W.; McBryan, J.; Harvey, H.; Lajczak, N.; Madden, S.F.; Pellissier, B.; Borgese, F.; Soriani, O.; et al. Bidirectional KCNQ1: $\beta$-catenin interaction drives colorectal cancer cell differentiation. Proc. Natl. Acad. Sci. USA 2017, 114, 4159-4164. [CrossRef]

52. Fan, H.; Zhang, M.; Liu, W. Hypermethylated KCNQ1 acts as a tumor suppressor in hepatocellular carcinoma. Biochem. Biophys. Res. Commun. 2018, 503, 3100-3107. [CrossRef]

53. Strubberg, A.M.; Liu, J.; Walker, N.M.; Stefanski, C.D.; MacLeod, R.J.; Magness, S.T.; Clarke, L.L. Cftr Modulates Wnt/ $\beta$-Catenin Signaling and Stem Cell Proliferation in Murine Intestine. Cell. Mol. Gastroenterol. Hepatol. 2018, 5, 253-271. [CrossRef]

54. Xie, R.; Xu, J.; Xiao, Y.; Wu, J.; Wan, H.; Tang, B.; Liu, J.; Fan, Y.; Wang, S.; Wu, Y.; et al. Calcium Promotes Human Gastric Cancer via a Novel Coupling of Calcium-Sensing Receptor and TRPV4 Channel. Cancer Res. 2017, 77, 6499-6512. [CrossRef]

55. Wang, T.; Chen, Z.; Zhu, Y.; Pan, Q.; Liu, Y.; Qi, X.; Jin, L.; Jin, J.; Ma, X.; Hua, D. Inhibition of Transient Receptor Potential Channel 5 Reverses 5-Fluorouracil Resistance in Human Colorectal Cancer Cells. J. Biol. Chem. 2015, 290, 448-456. [CrossRef] [PubMed]

56. Wong, A.M.G.; Kong, K.L.; Chen, L.; Liu, M.; Wong, A.M.G.; Zhu, C.; Tsang, J.W.-H.; Guan, X.-Y. Characterization ofCACNA2D3as a putative tumor suppressor gene in the development and progression of nasopharyngeal carcinoma. Int. J. Cancer 2013, 133, 2284-2295. [CrossRef]

57. Jin, Y.; Cui, D.; Ren, J.; Wang, K.; Zeng, T.; Gao, L. CACNA2D3 is downregulated in gliomas and functions as a tumor suppressor. Mol. Carcinog. 2017, 56, 945-959. [CrossRef] [PubMed]

58. Than, B.L.N.; Linnekamp, J.F.; Starr, T.K.; Largaespada, D.A.; Rod, A.; Zhang, Y.; Bruner, V.; Abrahante, J.; Schumann, A.; Luczak, T.; et al. CFTR is a tumor suppressor gene in murine and human intestinal cancer. Oncogene 2016, 35. [CrossRef]

59. Chen, Z.; Tang, C.; Zhu, Y.; Xie, M.; He, D.; Pan, Q.; Zhang, P.; Hua, D.; Wang, T.; Jin, L.; et al. TrpC5 regulates differentiation through the $\mathrm{Ca}^{2+} /$ Wnt5a signalling pathway in colorectal cancer. Clin. Sci. 2017, 131, 227-237. [CrossRef]

60. Sagredo, A.I.; Sagredo, E.A.; Cappelli, C.; Báez, P.; Andaur, R.E.; Blanco, C.; Tapia, J.C.; Echeverría, C.; Cerda, O.; Stutzin, A.; et al. TRPM4 regulates Akt/GSK3- $\beta$ activity and enhances $\beta$-catenin signaling and cell proliferation in prostate cancer cells. Mol. Oncol. 2017, 12, 151-165. [CrossRef]

61. Kudou, M.; Shiozaki, A.; Yamazato, Y.; Katsurahara, K.; Kosuga, T.; Shoda, K.; Arita, T.; Konishi, H.; Komatsu, S.; Kubota, T.; et al. The expression and role of TRPV2 in esophageal squamous cell carcinoma. Sci. Rep. 2019, 9, 16055. [CrossRef] [PubMed]

62. Schickling, B.M.; England, S.K.; Aykin-Burns, N.; Norian, L.A.; Leslie, K.K.; Frieden-Korovkina, V.P. BKCa channel inhibitor modulates the tumorigenic ability of hormone-independent breast cancer cells via the Wnt pathway. Oncol. Rep. 2014, 33, 533-538. [CrossRef]

63. Boassa, D.; Stamer, W.D.; Yool, A.J. Ion Channel Function of Aquaporin-1 Natively Expressed in Choroid Plexus. J. Neurosci. 2006, 26, 7811-7819. [CrossRef] [PubMed]

64. Liu, C.; Liu, L.; Zhang, Y.; Jing, H. Molecular mechanism of aquapontin (AQP3) in regulating differentiation and apoptosis of lung cancer stem cells through Wnt/GSK-3 $\beta / \beta$-Catenin pathway. J. BUON Off. J. Balk. Union Oncol. 2020, $25,828-834$.

65. Zhou, Y.; Wang, Y.; Wen, J.; Zhao, H.; Dong, X.; Zhang, Z.; Wang, S.; Shen, L. Aquaporin 3 promotes the stem-like properties of gastric cancer cells via Wnt/GSK-3 $\beta / \beta$-catenin pathway. Oncotarget 2016, 7, 16529-16541. [CrossRef] [PubMed] 
66. Liao, S.; Chen, H.; Liu, M.; Gan, L.; Li, C.; Zhang, W.; Lv, L.; Mei, Z. Aquaporin 9 inhibits growth and metastasis of hepatocellular carcinoma cells via Wnt/ $\beta$-catenin pathway. Aging 2020, 12, 1527-1544. [CrossRef]

67. Tan, S.H.; Swathi, Y.; Tan, S.; Goh, J.; Seishima, R.; Murakami, K.; Oshima, M.; Tsuji, T.; Phuah, P.; Tan, L.T.; et al. AQP5 enriches for stem cells and cancer origins in the distal stomach. Nat. Cell Biol. 2020, 578, 437-443. [CrossRef]

68. Leanza, L.; Zoratti, M.; Gulbins, E.; Szabo, I.L. Mitochondrial ion channels as oncological targets. Oncogene 2014, 33, 5569-5581. [CrossRef]

69. Leanza, L.; Romio, M.; Becker, K.A.; Azzolini, M.; Trentin, L.; Manago, A.; Venturini, E.; Zaccagnino, A.; Mattarei, A.; Carraretto, L.; et al. Direct Pharmacological Targeting of a Mitochondrial Ion Channel Selectively Kills Tumor Cells In Vivo. Cancer Cell 2017, 31, 516-531. [CrossRef] [PubMed]

70. Liu, L.; Chen, Y.; Zhang, Q.; Li, C. Silencing of KCNA1 suppresses the cervical cancer development via mitochondria damage. Channels 2019, 13, 321-330. [CrossRef]

71. Suisse, A.; Treisman, J.E. Reduced SERCA Function Preferentially Affects Wnt Signaling by Retaining E-Cadherin in the Endoplasmic Reticulum. Cell Rep. 2019, 26, 322-329.e3. [CrossRef]

72. Serafino, A.; Giovannini, D.; Rossi, S.; Cozzolino, M. Targeting the Wnt/ $\beta$-catenin pathway in neurodegenerative diseases: Recent approaches and current challenges. Expert Opin. Drug Discov. 2020, 15, 803-822. [CrossRef] [PubMed]

73. Inestrosa, N.C.; Tapia-Rojas, C. Loss of canonical Wnt signaling is involved in the pathogenesis of Alzheimer's disease. Neural Regen. Res. 2018, 13, 1705-1710. [CrossRef]

74. Aghaizu, N.D.; Jin, H.; Whiting, P.J. Dysregulated Wnt Signalling in the Alzheimer's Brain. Brain Sci. 2020, 10, 902. [CrossRef] [PubMed]

75. Wan, X.-Z.; Li, B.; Li, Y.-C.; Yang, X.-L.; Zhang, W.; Zhong, L.; Tang, S.-J. Activation of NMDA Receptors Upregulates A Disintegrin and Metalloproteinase 10 via a Wnt/MAPK Signaling Pathway. J. Neurosci. 2012, 32, 3910-3916. [CrossRef]

76. Stephano, F.; Nolte, S.; Hoffmann, J.; El-Kholy, S.; Von Frieling, J.; Bruchhaus, I.; Fink, C.; Roeder, T. Impaired Wnt signaling in dopamine containing neurons is associated with pathogenesis in a rotenone triggered Drosophila Parkinson's disease model. Sci. Rep. 2018, 8, 2372. [CrossRef]

77. Marchetti, B. Wnt/ $\beta$-Catenin Signaling Pathway Governs a Full Program for Dopaminergic Neuron Survival, Neurorescue and Regeneration in the MPTP Mouse Model of Parkinson's Disease. Int. J. Mol. Sci. 2018, 19, 3743. [CrossRef] [PubMed]

78. Pinto, C.; Medinas, D.B.; Fuentes-Villalobos, F.; Maripillán, J.; Castro, A.F.; Martínez, A.D.; Osses, N.; Hetz, C.; Henríquez, J.P. $\beta$-catenin aggregation in models of ALS motor neurons: GSK3 $\beta$ inhibition effect and neuronal differentiation. Neurobiol. Dis. 2019, 130, 104497. [CrossRef]

79. Gonzalez-Fernandez, C.; González, P.; Rodríguez, F. New insights into Wnt signaling alterations in amyotrophic lateral sclerosis: A potential therapeutic target? Neural Regen. Res. 2020, 15. [CrossRef] [PubMed]

80. Inestrosa, N.C.; Godoy, J.A.; Vargas, J.Y.; Arrázola, M.S.; Rios, J.A.; Carvajal, F.J.; Serrano, F.G.; Farías, G.G. Nicotine Prevents Synaptic Impairment Induced by Amyloid- $\beta$ Oligomers Through $\alpha 7-$ Nicotinic Acetylcholine Receptor Activation. NeuroMolecular Med. 2013, 15, 549-569. [CrossRef]

81. Thomsen, M.S.; Andreasen, J.T.; Arvaniti, M.; Kohlmeier, K.A. Nicotinic Acetylcholine Receptors in the Pathophysiology of Al zheimer's Disease: The Role of Protein-Protein Interactions in Current and Future Treatment. Curr. Pharm. Des. 2016, 22, 2015-2034. [CrossRef] [PubMed]

82. Liu, Y.; Hao, S.; Yang, B.; Fan, Y.; Qin, X.; Chen, Y.; Hu, J. Wnt/ $\beta$-catenin signaling plays an essential role in $\alpha 7$ nicotinic receptor-mediated neuroprotection of dopaminergic neurons in a mouse Parkinson's disease model. Biochem. Pharmacol. 2017, 140, 115-123. [CrossRef] [PubMed]

83. McQuate, A.; Latorre-Esteves, E.; Barria, A. A Wnt/Calcium Signaling Cascade Regulates Neuronal Excitability and Trafficking of NMDARs. Cell Rep. 2017, 21, 60-69. [CrossRef]

84. Yu, B.; Zhang, J.; Li, H.; Sun, X. Silencing of aquaporin1 activates the Wnt signaling pathway to improve cognitive function in a mouse model of Alzheimer's disease. Gene 2020, 755, 144904. [CrossRef]

85. Liu, Y.; Yang, R.; Liu, X.; Zhou, Y.; Qu, C.; Kikuiri, T.; Wang, S.; Zandi, E.; Du, J.; Ambudkar, I.S.; et al. Hydrogen Sulfide Maintains Mesenchymal Stem Cell Function and Bone Homeostasis via Regulation of Ca2+ Channel Sulfhydration. Cell Stem Cell 2014, 15, 66-78. [CrossRef]

86. Fei, D.; Zhang, Y.; Wu, J.; Zhang, H.; Liu, A.; He, X.; Wang, J.; Li, B.; Wang, Q.; Jin, Y. Cav 1.2 regulates osteogenesis of bone marrow-derived mesenchymal stem cells via canonical Wnt pathway in age-related osteoporosis. Aging Cell 2019, 18 , e12967. [CrossRef] [PubMed]

87. Lee, E.J.; Seo, E.; Kim, J.W.; Nam, S.A.; Lee, J.Y.; Jun, J.; Oh, S.; Park, M.; Jho, E.-H.; Yoo, K.H.; et al. TAZ/Wnt- $\beta$-catenin/c-MYC axis regulates cystogenesis in polycystic kidney disease. Proc. Natl. Acad. Sci. USA 2020, 117, 29001-29012. [CrossRef]

88. Harris, P.C.; Torres, V.E. Polycystic Kidney Disease. Annu. Rev. Med. 2009, 60. [CrossRef]

89. Shu, C.; Shu, Y.; Gao, Y.; Chi, H.; Han, J. Inhibitory effect of AQP1 silencing on adhesion and angiogenesis in ectopic endometrial cells of mice with endometriosis through activating the Wnt signaling pathway. Cell Cycle 2019, 18, 2026-2039. [CrossRef]

90. Lu, J.; Xu, F.; Zhang, Y.; Lu, H.; Zhang, J. ClC-2 knockdown prevents cerebrovascular remodeling via inhibition of the Wnt/ $\beta$ catenin signaling pathway. Cell. Mol. Biol. Lett. 2018, 23, 29. [CrossRef] 
91. Middelbeek, J.; Visser, D.; Henneman, L.; Kamermans, A.; Kuipers, A.J.; Hoogerbrugge, P.M.; Jalink, K.; Van Leeuwen, F.N. TRPM7 maintains progenitor-like features of neuroblastoma cells: Implications for metastasis formation. Oncotarget 2015, 6, 8760-8776. [CrossRef]

92. Xu, X.; Dai, Y.; Feng, L.; Zhang, H.; Hu, Y.; Xu, L.; Zhu, X.; Jiang, Y. Knockdown of Nav1.5 inhibits cell proliferation, migration and invasion via Wnt/ $\beta$-catenin signaling pathway in oral squamous cell carcinoma. Acta Biochim. Biophys. Sin. 2020, 52, 527-535. [CrossRef]

93. $\mathrm{Mu}, \mathrm{H} . ; \mathrm{Mu}, \mathrm{L} . ; \mathrm{Gao}, \mathrm{J}$. Suppression of CLC-3 reduces the proliferation, invasion and migration of colorectal cancer through Wnt/ $\beta$-catenin signaling pathway. Biochem. Biophys. Res. Commun. 2020, 533, 1240-1246. [CrossRef]

94. Li, X.; Hu, W.; Zhou, J.; Huang, Y.; Peng, J.; Yuan, Y.; Yu, J.; Zheng, S. CLCA1 suppresses colorectal cancer aggressiveness via inhibition of the Wnt/beta-catenin signaling pathway. Cell Commun. Signal. 2017, 15, 1-13. [CrossRef] 